\title{
PENGARUH EKSTRAK SEREH (Cymbopogon citratus DC) TERHADAP PREVALENSI DAN SURVIVAL BENIH IKAN MAS (Cyprinus carpio L) YANG DIINFEKSI BAKTERI Edwardsiella tarda
}

\section{EFFECK OF LEMON GRASS QUINTESSENCE (Cymbopogon citrates DC) ON PREVALENCE AND SURVIVAL GOLDFISH (Cyprinus carpio L) SEED INFECTED BY Edwardsiella tarda BACTERIA}

\author{
Farah Diana $^{1 *}$, Ika Andila ${ }^{2}$, Eri Safutra ${ }^{1}$ \\ ${ }^{1}$ Jurusan Akuakultur, Fakultas Perikanan dan Ilmu Kelautan, Universitas Teuku Umar, Aceh Barat \\ ${ }^{2}$ Jurusan Perikanan, Fakultas Perikanan dan Ilmu Kelautan, Universitas Teuku Umar, Aceh Barat \\ *Korespondensi: farahdiana@utu.ac.id
}

\begin{abstract}
ABSTRAK
Penelitian ini bertujuan untuk mengetahuai pengaruh ekstrak sereh (Cymbopogon citratus DC) terhadap prevalensi dan survival benih ikan mas yang diinfeksi Edwardsiella tarda serta mengetahui konsentrasi terbaik bahan ini sebagai imunostimulan maupun dalam pengobatan ikan mas yang terserang Edwardsiella tarda. Penelitian ini dilakukan pada bulan Maret s/d Desember 2016 bertempat di Hachery Fakultas Perikanan dan Ilmu Kelautan Universitas Teuku Umar Kabupaten Aceh Barat. Metode yang digunakan dalam penelitian ini adalah metode eksperimental dengan menggunakan rancangan acak lengkap (RAL), masing-masing dengan 4 taraf perlakuan dan 3 kali ulangan yaitu: P0 (kontrol) $=0$ ppm, P1 $=400$ ppm, P2 $=600$ ppm dan P3 $=800$ ppm. Hasil penelitian diperoleh bahwa penambahan berbagai dosis ekstrak sereh (Cymbopogon citratus DC) berpengaruh tidak nyata terhadap prevalensi benih ikan mas yang dilakukan pengamatan selama 7 hari dengan konsentrasi bakteri $10^{7} \mathrm{Sel} / \mathrm{ml}$ berada pada kisaran $73,33-93,33 \%$. Dan pada pengujian statistik diperoleh bahwa F-hit $(1,111111)<F-t a b \quad 0,05 \quad(4,066181)$, akan tetapi berpengaruh sangat nyata $(\mathrm{P}>0,05)$ terhadap persentase kelangsungan hidup, hasil pengujian statistik diperoleh F-hit $(8,407407)>$ F-tab 0,05 (4,066181).
\end{abstract}

Kata kunci: Cymbopogon citratus DC, Cyprinus carpio L, Edwardsiella tarda.

\begin{abstract}
This research aimed to determine effects of lemongrass' quintessence (Cymbopogon citrates DC) on prevalence and survival goldfish (Cyprinus carpio L) seed whose infected by Edwardsiella tarda and to determine great concentration of it's as immunostimunostimulatory as well as goldfish seed' treatment whose infected by Edwardsiella tarda. This research has been conducted on March till December 2016 in Fisheries and Marine Science Faculty Hacthery Teuku Umar University West Aceh district. This research methods was exsperimental, with a completely randomized design $(\mathrm{CDR})$, each with 4 treatment and 3 repetitions there are: $\mathrm{P} 0$ (control) $=0 \mathrm{ppm}, 400 \mathrm{ppm}=$ $\mathrm{P} 1, \mathrm{P} 2$ and $\mathrm{P} 3=600 \mathrm{ppm}=800 \mathrm{ppm}$. Results showed the addition of various doses of lemongrass quintessence (Cybopogon citrates DC) not significantly effect on goldfish seed prevalence were observed for 7 days at $10^{7}$ bacterial cells/ml concentration in 73.33 to $93.33 \%$ range. And statistical tests showed F-hit (1.111111) <F-tab 0.05 (4.066181).
\end{abstract}

Keywords: Cybopogon citrates DC, Cyprinus carpio L, Edwardsiella tarda

*Fakultas Perikanan dan Ilmu Kelautan, Universitas Teuku Umar

Korespondensi : Jurusan Akuakultur, Fakultas Perikanan dan Ilmu Kelautan, Universitas Teuku Umar, Kampus UTU Meulaboh, Alue Peunyareng 23615, Telp: +62 81360272409, email: farahdiana@utu.ac.id 


\section{PENDAHULUAN}

Ikan mengandung protein yang cukup tinggi dan komposisi asam aminonya tidak sama dengan hewan-hewan darat. Ikan mas (Cyprinus carpio L) merupakan salah satu hasil perairan yang memiliki kandungan gizi tinggi dan bernilai ekonomis penting, sehingga sepantasnya mendapat penanganan yang cukup serius. Penerapan teknik penanganan yang baik dapat mempertahankan mutu ikan. Kemunduran mutu ikan segar umumnya disebabkan oleh aktifitas mikrobiologis yang sudah ada secara alami pada perairan yang tinggi bahan organik. Salah satu faktor yang sangat penting dalam usaha budidaya perikanan adalah ketersediaan benih yang bebas dari hama dan penyakit ikan serta berkualitas tinggi yang akan memacu perkembangan budidaya perikanan dengan cepat (Murtidjo, 2001).

Namun temuan dilapangan ternyata masalah terbesar yang menjadi penghambat budidaya ikan ini adalah munculnya serangan penyakit. Penyakit yang menyerang ikan air tawar disebabkan oleh bakteri, jamur. Salah satu bakteri yang biasa menyerang ikan ini adalah Edwardsiella tarda yang sampai saat ini masih menjadi ancaman dalam usaha budidaya ikan air tawar. (Kodama, et al., 1987 dalam Septiama, dkk., 2008). Para pembudidaya ikan umumnya menggunakan zat kimia atau antibiotik dalam menanggulangi penyakit. Namun, penggunaan antibiotik dalam jangka waktu lama akan berdampak negatif, diantaranya dapat menimbulkan resistensi terhadap bakteri patogen, memerlukan biaya yang mahal, dan residu antibiotik dapat terakumulasi pada ikan. Upaya lain yang dilakukan untuk mengobati penyakit ini adalah dengan menggunakan bahan alami yang mengandung senyawa antibakteri (Ikbal, 2011).

Berkaitan dengan permasalahan di atas, perlunya alternatif bahan obat yang lebih aman dan dapat digunakan dalam pengendalian penyakit ikan. Salah satu alternatifnya adalah menggunakan tumbuhan obat tradisional yang bersifat antiparasit, antijamur, antiviral, dan khususnya antibakteri. Beberapa keuntungan menggunakan tumbuhan obat tradisional antara lain: relatif lebih aman, mudah diperoleh, murah, tidak menimbulkan resistensi, dan relatif tidak berbahaya terhadap lingkungan sekitarnya (Putra, 2015). Olehnya Indonesia yang memiliki keanekaragaman tanaman tradisional yang cukup melimpah dapat menjadi sumber senyawa tersebut, salah satu contoh tanaman yang diindikasikan memiliki sifat antibakteri yaitu sereh Cymbopogon citratus DC.

Tanaman sereh merupakan tanaman herbal, berasal dari Suku Poaceae yang digunakan sebagai pembangkit cita rasa pada makanan dan dipercaya pula dapat dimanfaatkan dalam pengobatan tradisional. Penyelidikan fitokimia mengungkapkan bahwa ekstrak sereh berisi beberapa nabati konstituen, yaitu: minyak atsiri (Leung et al, 1980), saponin, tanin, alkaloid dan flavonoid (Hamza et al. 2009). Berbagai kandungan senyawa aktif tersebut, mengindikasikan sereh memiliki aktivitas antibakteri yang cukup besar (Jafari et al. 2012), khususnya kandungan minyak atsiri.

Maka dari itu perlu dilakukan penelitian lebih lanjut tentang pengaruh pemberian ekstrak sereh terhadap prevalensi dan kelulushidupan benih ikan mas yang diinfeksi dengan bakteri Edwardsiella tarda yang dicoba pada skala laboratorium.

\section{METODE PENELITIAN}

Penelitian ini dilaksanakan pada Maret sampai dengan Desember 2016 bertempat di Laboratorium Hayati MIPA Unsyiah, di Laboratotium Ilmu dan Teknologi Pengolahan Susu Unsyiah di, Hachery Fakultas Perikanan UTU, Meulaboh.

\section{Prosedur Penelitian}

Ekstraksi dan Maserasi

Batang sereh yang telah dibersihkan, kemudian dikeringanginkan selama \pm 3 jam dan dicincang lalu dimasukkan kedalam wadah, kemudian batang sereh dimasukkan kedalam maserator dan diisi dengan etanol sebanyak $230 \mathrm{ml}$. Maserasi dilakukan tiga kali 24 jam. Selanjutnya filtrat hasil maserasi disaring dan ditampung dalam erlemeyer sehingga diperoleh filtrat ekstrak etanol dipekatkan dengan rotary evaporator pada suhu $40^{\circ} \mathrm{C}$ dengan kecepatan $120 \mathrm{rpm}$, sampai diperoleh ekstrak pekat (Rosidah dan Afiziah, 2012). 
1. Uji Fitokimia
a. Uji alkaloid
b. Uji steroid, terpenoid dan saponin
c. Uji flavonoid
d. Uji tanin
e. Uji fenolik
f. Uji daya hambat

\section{Pelaksanaan Penelitian \\ Persiapan Wadah}

Wadah yang digunakan untuk penginfeksian serta penampungan ikan sementara berupa akuarium dengan ukuran 40x30x30 cm yang telah disediakan dicuci bersih dan dikeringkan. Selanjutnya akuarium diisi air sebanyak 36 liter.

\section{Aklimatisasi Ikan}

Ikan yang diperoleh dari petani budidaya ikan di Nagan Raya dilakukan Aklimatisasi selama 1 hari dengan mengadaptasikan ikan dari tempat aslinya ke tempat baru. Ikan mas sebanyak 60 ekor ukuran 5-7 cm dipelihara dalam akuarium ukuran 40x30x30 cm dengan volume air 36 liter. Pakan diberikan dalam bentuk pellet FF999 sebanyak 0,9 gram (3\%BB/hari) dengan frekuensi 2 kali sehari, yaitu pagi dan sore hari.

\section{Penginfeksian Bakteri Pada Ikan Mas}

Berdasarkan penelitian yang dilakukan Sari (2014) uji in vivo dilakukan dengan $10^{7} \mathrm{sel} / \mathrm{ml}$ dengan dosis $0.1 \mathrm{ml} / \mathrm{ekor}$. Bakteri dari konsentrasi awal $6 \mathrm{ml}$ diambil kemudian diencerkan dalam 10 liter air tawar.

\section{Peletakan Benih Ikan Mas}

Setelah melakukan persiapan wadah penginfeksian, selanjutnya dimasukkan 60 ekor benih ikan mas ke dalam wadah yang telah disediakan dibiarkan dan direndam selama \pm 4 jam sampai ikan menunjukkan gejala-gejala klinis.

\section{Pembuatan Larutan Induk}

Pembuatan larutan induk dilakukan dengan melarutkan ekstrak batang serai kedalam air. Selanjutnya dihasilkan volume larutan induk dengan konsentrasi yang berbeda yakni P0. 0 liter (Kontrol), P1. 2 liter, P2. 3 liter, dan P3. 4 liter, dan jika dijumlahkan menghasilkan 9 liter larutan induk (dari 9 liter air dimasukkan 9 gram ekstrak batang serai). Setiap perlakuan dilakukan sebanyak 3 kali ulangan sehingga total air yang digunakan adalah 27 liter.

\section{Pemberian Perlakuan Ekstrak Sereh}

Setelah benih ikan mas dimasukkan kedalam tiap wadah dengan volume air 5 liter perwadah, selanjutnya dilakukan pengurangan volume air di tiap-tiap wadah perlakuan sesuai terhadap volume larutan induk ekstrak dengan konsentrasi yang berbeda sebagai perlakuan yakni wadah perlakuan P0. 5 liter -0 liter $=5$ liter; wadah perlakuan P1. 5 liter -2 liter $=3$ liter; wadah perlakuan P2.5 liter -3 liter $=2$ liter; dan wadah perlakuan P3.5 liter - 4 liter $=1$ liter. Selanjutnya dilakukan proses percampuran larutan induk sesuai konsentrasi kedalam tiap-tiap wadah yakni Wadah perlakuan P0. 5 liter air Wadah +0 liter larutan induk $=5$ liter; Wadah perlakuan P1. 3 liter air wadah +2 liter larutan induk $=5$ liter; wadah perlakuan P2. 2 liter air Wadah + 3 liter larutan induk $=5$ liter; dan Wadah perlakuan P3. 1 liter air Wadah + 4liter larutan induk $=5$ liter. Masing-masing perlakuan diulang sebanyak 3 kali pengulangan.

\section{Masa pemeliharaan}

Selama pemeliharaan ikan diberi pakan yang cukup, kemudian dilakukan penyiponan 1 kali sehari dengan tujuan untuk menjaga kualitas air. Pengamatan dilakukan selama masa pemeliharaan dan data yang digunakan adalah yang terakhir yaitu hari ketujuh. Pengukuran kualitas air tiap 2 hari sekali.

\section{Parameter Uji}

Parameter Utama

Parameter utama yang diamati dalam penelitian ini ada dua yaitu prevalensi dan survival benih ikan mas.

Prevalensi ikan mas

Perhitungan prevalensi dilakukan sebelum penghitungan kelulushidupan (SR) yang bertujuan untuk melihat sebarapa banyak ikan yang terinfeksi bakteri disetiap perlakuan.

\section{Survival Rate (SR)}

Penghitungan kelulushidupan (SR) ikan mas dilakukan setelah perhitungan prevalensi dilakukan atau pada akhir penelitian. 


\section{Analisis Data}

Data yang diperoleh dari penelitian ini berupa data prevalensi, dan kelangsungan hidup ikan mas dianalisis secara statistik menggunakan analisis ragam (Uji F). Bila terdapat perbedaan nyata dilanjutkan dengan uji lanjut Beda Nyata Terkecil (BNT) dan data kualitas air dianalisa secara deskriptif (Hanafiah, 2004)

\section{HASIL DAN PEMBAHASAN}

Prevalensi Benih Ikan Mas (\%)

Berdasarkan pengamatan yang dilakukan pada setiap wadah percobaan penginfeksian benih ikan mas dengan kepadatan bakteri $10^{7} \mathrm{Sel} / \mathrm{mL}$ tergolong positif terserang Edwardsiella tarda. menunjukkan hasil yang berbeda pada setiap perlakuan. Dengan diketahuinya total ikan uji yang hidup hingga akhir penelitian, maka dapat diketahui pula persentase kelulushidupannya, seperti yang disajikan pada Gambar 2.

Hasil perhitungan ANOVA menunjukan bahwa penggunaan ekstrak batang serai sebagai antibakteri Edwardsiella tarda pada ikan mas berpengaruh sangat nyata terhadap tingkat kelangsungan hidup benih ikan mas. Nilai SR maksimum terdapat pada perlakuan P1 yaitu 93,33\%, diikuti P2 dengan rata-rata $80 \%$, dan selanjutnya $\mathrm{P} 3$ yaitu 73,33\% dan Kontrol (K) sebesar 26,66\%.

Berdasarkan hasil uji lanjut Beda Nyata Terkecil (BNT) pada selang kepercayaan $95 \%$, diperoleh hasil berbeda sangat nyata pada setiap perlakuan.

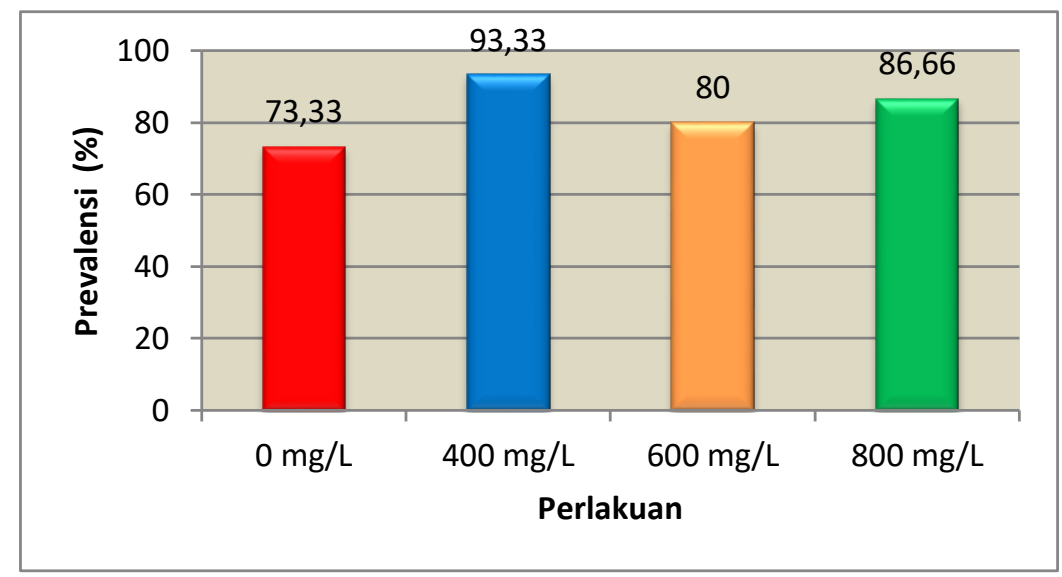

Gambar 1. Prevalensi Benih Ikan Mas yang Diinfeksikan Bakteri Edwardsiella tarda

\begin{abstract}
Berdasarkan hasil uji ANOVA diperoleh bahwa konsentrasi bakteri Edwardsiella tarda $10^{7} \quad \mathrm{Sel} / \mathrm{ml}$ tidak berpengaruh nyata pada setiap perlakuan. Nilai prevalensi maksimum terdapat pada perlakuan $\mathrm{P} 1$ yaitu 93,33\%, diikuti $\mathrm{P} 3$ dengan rata-rata $86,66 \%$, selanjutnya perlakuan $\mathrm{P} 2$ $80 \%$ dan Kontrol sebesar 73,33\%.

Berdasarkan hasil uji lanjut Beda Nyata Terkecil (BNT) pada selang kepercayaan 95\%, diperoleh hasil tidak ada perbedaan nyata pada setiap perlakuan.
\end{abstract}

\section{Tingkat Kelangsungan Hidup (\%)}

Kelulushidupan pada ikan mas yang dilakukan selama 7 hari dapat diketahui prosentase kelulushidupannya. Jumlah ikan mas yang hidup hingga akhir penelitian
Uji Fitokimia Batang Sereh

Dari hasil pengujian fitokimia secara kualitatif, ekstrak sereh dengan menggunakan pelarut etanol, memperlihatkan bahwa secara keseluruhan ekstrak sereh mengandung senyawa metabolit sekunder seperti alkaloid, steroid, terpenoid fenolik/tanin/flavonoid dan saponin (Tabel 1).

\section{Kualitas Air}

Adapun parameter kualitas air yang diamati dalam penelitian ini meliputi suhu dan $\mathrm{pH}$. Hasil pengukuran kualitas air selama penelitian menunjukkan bahwa nilai-nilai kualitas air yang diperoleh pada Tabel 2 berada dalam kisaran yang optimum untuk pemeliharaan ikan mas. 
Tabel 1. Hasil uji fotokimia sampel segar batang serai.

\begin{tabular}{lccc}
\hline \multicolumn{1}{c}{ Kandungan Kimia } & Reagen & $+/-$ & Hasil Pengamatan \\
\hline Alkaloid & Mayer & - & Endapan Putih \\
& Wagner & - & Endapan Coklat \\
& Dragendorff & - & Endapan Merah \\
Steroid & Uji Liebermann & + & Hijau \\
Terpenoid & Uji Liebermann & + & Merah \\
Saponin & Pengocokan & + & Berbusa \\
Flavonoid & 0,5 g Mg danHCl & + & Merah muda \\
Tanin & $\mathrm{FeCl}_{3}$ & + & Hijau Kehitaman \\
Fenolik & Etanol+FeCl $_{3}$ & + & Biru Kehitaman \\
\hline
\end{tabular}

Keterangan: (+) menunjukkan hasil positif dan (-) menunjukkan hasil negatif.

Tabel 2. Parameter Kualitas Air

\begin{tabular}{ccccccc}
\hline \multirow{2}{*}{ No } & \multirow{2}{*}{ Parameter Kualitas Air } & \multicolumn{4}{c}{ Perlakuan } & \multirow{2}{*}{ Standar Kualitas } \\
\cline { 3 - 6 } & & $\mathrm{K}$ & $\mathrm{P} 1$ & $\mathrm{P} 2$ & $\mathrm{P} 3$ & Air \\
\hline 1 & Suhu $\left({ }^{\circ} \mathrm{C}\right)$ & $25-27$ & $25-28$ & $25-28$ & $25-28$ & $20-28$ \\
2 & $\mathrm{pH}$ & $6,8-7,2$ & $6,8-7,2$ & $6,8-7,2$ & $6,8-7,2$ & $6,5-8,5$ \\
\hline
\end{tabular}

Menurut agus (2011), menyatakan bahwa ikan mas mampu berkembang dengan baik dengan kisaran suhu $20-28\left({ }^{\circ} \mathrm{C}\right)$ dengan $\mathrm{pH}$ 6,5-8,5 dan DO 3-5 $\mathrm{mg} / \mathrm{L}$. dengan demikian dapat disimpulkan bahwa kualitas air selama penelitian memenuhi persyaratan optimum untuk budidaya ikan mas.

Prevalensi adalah seberapa sering suatu penyakit atau kondisi terjadi pada sekelompok spesies (Pujiastuti, 2015). Prevalensi tertinggi dalam penelitian terdapat pada perlakuan P1 yaitu 93,33\% (Gambar 2). Pada setiap norlolwan tardanat narhadon wang begitu besar

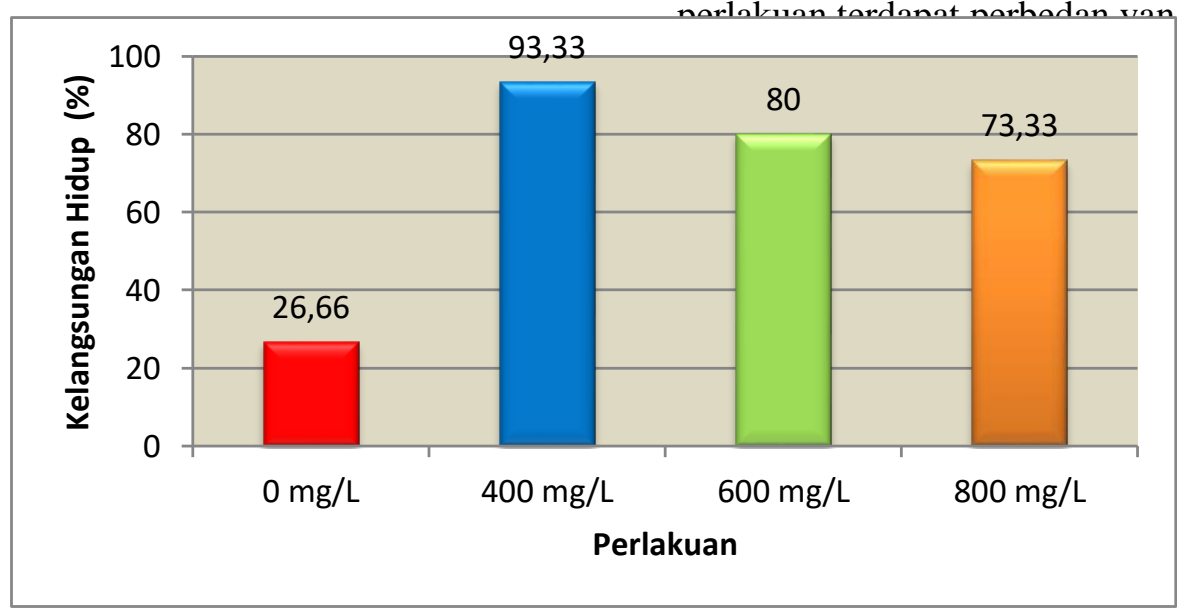

Gambar 2. Kelangsungan Hidup Benih Ikan Mas yang Diinfeksikan Bakteri Edwardsiella tarda 
Terjadinya peningkatan prevalensi setelah pemberian perlakuan ekstrak sereh pada tiap perlakuan diduga karena ikan mengalami stress akibat pemberian perlakuan ekstrak sereh, hal tersebut sesuai dengan pernyataan Irianto (2003) adanya tindakan pengobatan atau pencegahan penyakit dapat menyebabkan ikan mengalami stress dan ahirnya pertahanan tubuh melemah sehingga bakteri dengan mudah menginfeksi ikan tersebut.

Menurut Ratnawati (2013) Bakteri pathogen akan mudah menyerang pada ikan yang tingkat imunitasnya rendah. Infeksi $E$. tarda menunjukkan terjadi perubahan morfologi seperti perubahan warna, bentuk tubuh maupun gerakan berenang.

Hal ini disebabkan karena E. tarda menyerang bagian kulit ikan epidermis yang di dalamnya terdapat sel pigmen (chromotophore) dan kolagen yang memperkuat struktur kulit berkembang ke dermis dan otot, sehingga menyebabkan kulit melepuh dan kehilangan pigmen warna.

Melanomakrofag atau endapan coklat akibat infeksi $E$. tarda terjadi karenaadanya eksudasi kuman di dalam jaringan. Selain akibat infeksi $E$. tarda melanomakrofag dapat pula dijumpai pada ikan yang menderita Pseudomoniasis. Luka pada kulit akibat E. tarda yang sudah parah dapat menyebabkan ikan kehilangan keseimbangan sehingga gerakan berenangnya lemah atau kurang lincah dan kadang terbalik.

Menurut Effendie (2002) beberapa penyebab kematian terhadap populasi ikan adalah diambil oleh orang (fishing), pemangsaan, kerusakan alam dan penyakit, jadi penyakit merupakan salah satu dari mortalitas. Persentasi mortalitas tertinggi selama penelitian terdapat pada perlakuan Kontrol negatif yaitu sebesar 26,66\% (Gambar,1).
Gambar 1 menunjukkan kisaran kelulushidupan ikan mas selama penelitian adalah perlakuan P0 (26,66\%), P1 (93,33\%), P2 (80\%), dan P3 (73,33\%), kelulushidupan tertinggi terdapat pada perlakuan P1 yaitu 93\%. Hal ini sama dengan penelitian yang dilakukan Sari (2014) pada perlakuan penggunaan ekstrak bawang putih sebagai pencegahan Edwardsiella tarda mencapai tingkat kelulushidupan $76,67 \%$ pada konsentrasi terendah . Sehingga dalam penelitian ini apa bila dilihat dari kelulushidupan ekstrak sereh (Cymbopogon citratus DC) sudah mampu bekerja sebagai antibakteri. Hal tersebut ditunjang dengan hasil analisis ragam yang menunjukkan pemberrian ekstrak sereh memberikan pengaruh sangat nyata $(\mathrm{P}>0,05)$ terhadap kelulushidupan ikan mas pasca uji tantang.

Haryani at al.,(2012), menyatakan kemampuan ekstrak batang sereh dalam mengobati luka akibat infeksi bakteri Edwardsiella tarda karena tanaman ini mengandung senyawa kimia saponin, mekanisme saponin dalam menyembuhkan luka dengan memacu pembentukan kolagen, yaitu struktur protein yang berperan dalam proses penyembuhan luka. Surahman (1984), mengatakan zat-zat kimia tersebut sebagian besar termasuk dalam golongan minyak atsiri. Hasim (2003), menyatakan bahwa daya antibakteri minyak atsiri disebabkan oleh adanya senyawa fenol dan turunannya yang dapat mendenaturasi protein sel bakteri.

Kematian ikan mas pada perlakuan P0 (dosis $0 \mathrm{ppm}$ ) mengalami kematian hingga pada hari ke 7 dengan jumlah kematian 11 ekor, dimana pada perlakuan ini ikan uji diinfeksi bakteri $E$. tarda tetapi tidak dilakukan perendaman dengan ekstrak sereh. Perlakuan P3 (dosis 800 ppm) dengan jumlah kematian 4 ekor, P2 (dosis 600 ppm) dengan jumlah kematian 3 ekor. Perlakuan P1 (dosis $400 \mathrm{ppm}$ ) adalah perlakuan yang paling sedikit terjadi kematian dengan jumlah sebesar 1 ekor. Hal tersebut diduga karena kandungan senyawa aktif pada dosis ekstrak batang sereh $400 \mathrm{ppm}$ dapat ditoleril oleh ikan. Pelezar dan Chan (1986) berpendapat bahwa semakin tinggi konsentrasi antimikroba yang digunakan maka semakin cepat dalam membunuh bakteri, akan tetapi penggunaan konsentrasi yang teralu tinggi kurang efektif dalam pengobatan karena dapat membunuh 
ikan dan juga kurang ekonomis dalam pemanfaatannya.

Kematian tertinggi pada perlakuan terjadi pada hari pertama sebanyak 8 ekor dan diikuti pada hari ke-2 sebanyak 6 ekor dan diikuti pada hari ke-4 sebanyak 5 ekor. Ikan yang mati mengalami luka yang parah dengan terdapat borok pada bagian tubuhnya. Hal ini disebabkan karena kondisi ikan yang disebabkan oleh aktivitas bakteri Edwardsiella tarda.

Parameter kualitas air yang diamati selama penelitian yaitu parameter fisika seperti suhu $\left({ }^{\circ} \mathrm{C}\right)$ sedangkan parameter kimia seperti derajat keasaman $(\mathrm{pH})$. Suhu air selama perlakuan mengalami fluktuasi antara $25-28^{\circ} \mathrm{C}$ tetapi tetap berada dalam kisaran suhu yang baik bagi ikan. $\mathrm{pH}$ media pada perlakuan P0, P1, P2, dan P3 berada pada nilai $\mathrm{pH}$ toleransi untuk ikan mas yaitu antara 6-7. Menurut Agus (2001) ikan akan mengalami pertumbuhan yang optimal pada nilai $\mathrm{pH}$ antara 6,5-8,5. Hernowo 2013 juga berpendapat bahwa kisar air yang layak untuk kehidupan ikan yang optimal.

\section{KESIMPULAN}

\section{Berdasarkan hasil pengamatan Pengaruh Ekstrak Sereh (Cymbopogon citratus DC) terhadap Prevalensi dan Survival Benih Ikan Mas yang Diinfeksi Bakteri Edwardsiella tarda dapat disimpulkan bahwa: \\ 1. Prevalensi pada setiap perlakuan terdapat perbedaan yang begitu besar hal tersebut dikarenakan setiap ikan memiliki tingkat imunitas yang berbeda-beda. Persentase prevalensi tertinggi terdapat pada perlakuan P1 sebesar 93,33\%.}

2. Ekstrak batang serai paling efektif sebagai antibakteri Edwardsiella tarda pada benih ikan mas dengan konsentrasi $400 \mathrm{mg} / \mathrm{L}$ persentase kelulushidupan mencapai $93,33 \%$.

\section{DAFTAR PUSTAKA}

Achmadi, S.S., 1992, Kimia Organik, Edisi II, Erlangga, Jakarta.

Agus. 2011. Beberapa Metode Pembenihan Ikan Air Tawar. Yogyakarta: Kanisius.

Agus, A. 2001. Aroma terapi. Penerbit

Swadaya. Jakarta.
Affandi, R dan Tang, U.M. 2002. Fisiologi Hewan Air. Unri Press. Riau.

Afrianto, E dan E.Liviawaty. 1992. Pengendalian Hama dan Penyakit Ikan. : Penerbit KanasiusYogyakarta.

Amri, K. dan Khairuman. 2002. Menanggulangi Penyakit pada Ikan Mas dan Koi. Agro Media Pustaka. Jakarta.

Arora, D.S. dan Bhardwaj. 1997. Antibacterial Activity of Some Medicinal Plants. Geo. Bioscience, (24) : 127-131.

Austin,B \& D.A. Austin. (1987). Bacterial fish Phatogens; Disease in Farmed and Wild Fish. Ellis Horwood Limited. Chichester west Sussex, England.

BADAN POM RI. 2013. Jintan Hitam Sebagai Imunostimulan. InfoPOM Vol.14 No. 1 Januari-Februari 2013. Jakarta.

Baratta TM, Dorman DHJ, Deans SG, Figueiredo CA, Barroso JG. 1998. Antimicrobial and Antioxidant Properties of Some Commercial Essential Oils. Journal of Flavour Fragr, 13:44-235.

Barus, W. N. U. 2013. Uji Efektivitas Antibakteri Ekstrak Daun Kamboja (Plumiera rubra) pada Konsentrasi yang Berbeda terhadap Pertumbuhan Aeromonas hydrophila Secara In Vitro. Skripsi. Fakultas Pertanian Universitas Sumatra Utara. Medan.

Bassole IHN, Meda AL, Bayala B, Obame LC, Ilboudo AJ, Franz C, Novak J, Nebie RC and Dicko MH. 2011. Chemical Composition and Antimicrobial Activity of Cymbopogon citratus and Cymbopogon giganteus Essential Oils Alone and in Combination. Journal Phytomedicine, 18 (2011): 1070-1074.

Corbel, M.J. 1975. The immune response in fish: A review. J. Fish Biol., 7: 539563.

Corner, DE. 1995. Naturally Occuring Compounds in Antimicrobial in Food Eds., by Davidson PM and Branen AL. Eds. Marcel Dekker. New York.

Darmayasa, I.B.C. 2008. Daya Hambat Fraksinasi Ekstrak Sembung Dalan (Sphaerantus indicus L.) Terhadap Bakteri Escherichia coli dan 
Staphylococus aureus. Jurnal Biologi XI (2) : 74-77.

Effendi, M.I. 1992. Metode Biologi Perikanan, Penerbit Yayasan Agromedia. Bogor.

Fernando, C. F. J.L Furtado, A. V Gussev, G. Honek and S.A. Kakonge. 1972. Methods for the Study of Fresh Water Fish Parasites. University ofWaterloo. Biologi Series: 1-76

Fidyandini, H. P., Subekti, S., dan Kismiyati. 2012. Identifikasi dan Prevalensi Ektoparasit pada Ikan Bandeng (Chanos chanos) yang Dipelihara Di Karamba Jaring Apung Upbl Situbondo Dan Di Tambak Desa Bangunrejo Kecamatan Jabon Sidoarjo. Journal of Marine and Coastal Science, 1(2), 91 112, 2012.

Ganjewala D. Biochemical and molecular characterization ofgeraniol rich lemongrass (Cymbopogon flexuosus Nees exSteud) Wats. Mutant cv. GRL1. 2002 Thesis.

Guffin McM, Hobbs C, Upton R. 1997. American Herbal Products Association Botanical Savety Handbook. Boca Raton, CRC Press.

Gomez, K.A. \& A.A. Gomez. 1995. Statistical Procedures of Agricltural Research 2 Ed. An International Rice Research Institute Book John Willey and Sons. Losbanos.

Hamza, I. S., Sundus H. A., Hussaine A. 2009. Study the Antimocrobial Activity of Lemon Grass Leaf Extracts. 2:1

Hanafiah, K A. 2004. Rancangan Percobaan Teori dan Aplikasi. PT. Raja Grafindo Persada. Jakarta.

Handayani. M. 2015. Aktivitas Antimikroba Ekstrak Kulit Buah Manggis (Garciniamangostana) Terhadap Bakteri Aeromonas hydrophila, Edwardsiella tarda dan Jamur Saprolegnia.sp. Universitas Sumatera Utara. Medan.

Harjadi, 2010. Kandungan kimia batang serai. http://harjadi-pasukan berdarah.blogspot.com. Diakses tanggal 29 April 2016. 